\title{
Cesarean Section profile at a tertiary center
}

\author{
Madhu Shrestha, Shanti Shrestha \\ Department of Obstetrics and Gynecology, Paropakar Maternity and Women's Hospital, Kathmandu
}

Received: March 31, 2020

Accepted: May 5, 2020

\section{ABSTRACT}

Aim: To determine the incidence and indication of caesarean section.

Method: It is a retrospective cross sectional study conducted at Paropakar Maternity and Women's Hospital for three months. The data was retrieved from the medical record of operation theatre.

Results: During the study period, 31.1\% (1,592 out of 5,120) of women underwent caesarean section. Eighty eight percent (n-1,402) of them were emergency caesarean section while $12 \%$ were elective (n-190). Majority of the women (70.3\%) belonged to 20-29 years and half of them were primigravida. Around 89.2\% caesarean sections were performed at 37-42 weeks of gestation. The four leading indications were fetal distress (31.5\%), previous caesarean section (19.7\%), cephalo -pelvic disproportion (13.4\%) and abnormal presentation (7.9\%).

Conclusions: In this study, incidence of caesarean section is more than WHO recommendation. It may be mainly due to the referral of complicated cases from the periphery of the country.

Key words: caesarean section, indication

Citation : Shrestha M, Shrestha S. Cesarean Section profile at a tertiary center. Nep J Obstet Gynecol. 2020;15(30):68-71. DOI: 10.3126/ njog.v15i1.29345

\section{INTRODUCTION}

Caesarean section (CS), when indicated, saves the life of both mother and baby. For this purpose, WHO recommends to keep its rate between 10 $15 \%$. ${ }^{1}$ However, from last decade there has been tremendous increase in its rate worldwide without the reduction of maternal and neonatal morbidity as well as mortality. ${ }^{2}$ Changing maternal and fetal risk profile, older primipara, maternal request for $\mathrm{CS}$, non reassuring fetal heart rate tracing, fear of complication for the child and previous traumatic birth are thought to be responsible for increased CS. ${ }^{3}$ Safe and better surgical techniques, improved anesthesia, effective antibiotics and availability of blood transfusion also contribute indirectly to its increasing rate. ${ }^{4}$

The increasing trend of CS has been seen worldwide while the rate varies in between the institutions and regions. In African countries it varies from 3\% (in Sub Saharan countries) to $27.6 \%$ ( in Ethiopia). ${ }^{4}$ According to the WHO report, incidence in USA is

\section{CORRESPONDENCE}

Dr Madhu Shrestha

Paropakar Maternity and Women's Hospital, Thapathali, Kathmandu

Email: shresthamadhu74@gmail.com; Mobile: +977-9841286867
$32.2 \%$ while it is $24 \%$ in England, $27 \%$ in China and $50 \%$ in Brazil. ${ }^{5}$ In Nepal also, the incidence of CS varies from one facility to another one. It is reported to be $9.5 \%$ at Okhaldhunga Community Hospital, 18.8\% at Mid-Western Regional Hospital, Surkhet, $45.8 \%$ at Kathmandu Medical College, 50\% at Kirtipur hospital and $63.27 \%$ at Pachimanchal community hospital. ${ }^{1,6-9}$

Regarding the indication of CS, labor dystocia, fetal distress, malpresentation and previous caesarean delivery are the leading indications of caesarean delivery. ${ }^{10}$ Other common indications are cephalopelvic disorder (CPD), intra-uterine growth restriction (IUGR), placenta previa, small for gestational age, macrosomia and severe preeclampsia. ${ }^{11}$ Cesarean delivery on maternal request (CDMR) is planned $\mathrm{CS}$ in the absence of any medical or obstetric contraindication for vaginal delivery which is one of the emerging important reason for increased caesarean rate. ${ }^{3}$ Its incidence is also different in 
different countries ranging from $4-18 \%$ and mainly related with tocophobia and previous bad experience of labor. ${ }^{12}$ In a study done by Ji $\mathrm{H}$ et al, the incidence of CDMR was $13 \%$ to $17 \%$ in the second and third timester. ${ }^{13}$ In Brazil, a population based study found that there was a growing preference for CS among women. This study also observed that lower rate in nulliparous $(15.4 \%)$ in public based hospital and increased rate $(73.2 \%)$ among multiparous with previous CS in private health care. ${ }^{14}$ In addition, another reason for increasing $\mathrm{CS}$ rate is elective repeat $\mathrm{CS}$ which is related with the sense of security to both physician and mother. ${ }^{3}$ Though life saving, unnecessary CS may result into maternal as well as neonatal morbidity and mortality. It is also associated with increased health expenditure for families and exerts additional pressure upon overburdened health system, particularly in low and middle income countries like ours. ${ }^{14}$ This study aims to explore the incidence and indication of caesarean at this tertiary government hospital.

\section{METHOD}

This is a retrospective study of 1,592 women who had undergone caesarean sections at Paropakar Maternity Women's Hospital from mid January to mid April 2019. The data was retrieved from the register of Operation Theater and analyzed according to the maternal age, gravidity, parity, gestational age and indication of caesarean section.

\section{RESULT}

During the study period 5,120 women had delivered in this facility while 1,592 (31.1\%) of them underwent CS. Eighty eight percent $(n=1,402)$ of them were emergency CS while 12\% were elective CS (n-190). The women who underwent caesarean section ranged from 15 to 49 years while majority of them $(n=719$, $70.3 \%$ ) were between $20-29$ years [Table-1].

Table-1: Distribution according to the age $(n=1592)$

\begin{tabular}{|c|c|c|}
\hline Age in years & Number & Percentage \\
\hline $15-19$ & 124 & 7.8 \\
\hline $20-24$ & 578 & 36.3 \\
\hline $25-29$ & 541 & 34.0 \\
\hline $30-34$ & 220 & 13.8 \\
\hline $35-39$ & 105 & 6.6 \\
\hline $40-44$ & 22 & 1.4 \\
\hline$\geq 45$ & 2 & 0.1 \\
\hline
\end{tabular}

Around half of caesarean section occurred in primigravida $(n=796)$ while $55.5 \%$ of women $(n=884)$ who underwent CS were nulliparous [Table-2].

Table-2: Distribution according to Gravidity and Parity $(n=1592)$

\begin{tabular}{|c|c|c|}
\hline $\begin{array}{c}\text { Gravidity or } \\
\text { Parity }\end{array}$ & $\begin{array}{c}\text { Frequency by } \\
\text { Gravidity (\%) }\end{array}$ & $\begin{array}{c}\text { Frequency by } \\
\text { Parity (\%) }\end{array}$ \\
\hline 0 & NA & $884(55.5)$ \\
\hline 1 & $796(50)$ & $498(31.3)$ \\
\hline 2 & $499(31.3)$ & $151(9.5)$ \\
\hline 3 & $200(12.6)$ & $36(2.3)$ \\
\hline 4 & $64(4)$ & $8(0.5)$ \\
\hline$\geq 5$ & $33(2.1)$ & $15(0.9)$ \\
\hline
\end{tabular}

Majority of women ( $\mathrm{n}=1420,89 \%)$ underwent caesarean section at 37 to 42 gestational weeks of gestation while $0.6 \%$ underwent $\operatorname{CS~}(n=10)$ at less than 30 weeks of gestation [Table-3].

Table-3: Distribution by gestational age $(n=1592)$

\begin{tabular}{|c|c|}
\hline Gestational age in weeks & Number (\%) \\
\hline$<30$ & $10(0.6)$ \\
\hline $31-33$ & $31(1.9)$ \\
\hline $34-36$ & $95(6.0)$ \\
\hline $37-39$ & $769(48.3)$ \\
\hline $40-42$ & $651(40.9)$ \\
\hline$>42$ & $36(2.3)$ \\
\hline
\end{tabular}

The commonest indications of caesarean delivery were fetal distress $(n=497,31.5 \%)$, previous caesarean section $(n=313,19.7 \%)$, cephalo-pelvic disproportion $(n=214,13.4 \%)$ and abnormal presentation $(n=133$, $7.9 \%$ ) respectively. The other indication of CS include extreme maternal age, short stature, obesity, bad obstetric history, Diabetes, pregnancy after subfertility treatment, multiple medical complications , history of 3rd and 4th degree perineal tear, reduced fetal movement and fetal macrosomia [Table-4].

Table-4: Indications of caesarean delivery $(n=1592)$

\begin{tabular}{|l|c|c|}
\hline Indication & Number & Percentage \\
\hline Fetal distress & 497 & 31.5 \\
\hline Previous caesarean section & 313 & 19.7 \\
\hline Cephalo-pelvic disproportion & 214 & 13.4 \\
\hline Abnormal presentation & 133 & 7.9 \\
\hline Abnormal liquor volume & 97 & 6.1 \\
\hline Non reassuring CTG & 76 & 4.8 \\
\hline Hypertensive disorder & 68 & 4.3 \\
\hline
\end{tabular}




\begin{tabular}{|l|c|c|}
\hline Indication & Number & Percentage \\
\hline Non-progress of labor & 42 & 2.6 \\
\hline Failed induction of labor & 38 & 2.4 \\
\hline APH & 33 & 2.1 \\
\hline IUGR & 9 & 0.6 \\
\hline Twin & 9 & 0.6 \\
\hline Others & 58 & 3.6 \\
\hline
\end{tabular}

Majority of repeat caesarean sections were done for refusal to attempt vaginal delivery $(\mathrm{n}=105,33.4 \%)$, followed by post-dated pregnancy $(\mathrm{n}=40,12.8 \%)$ and advanced maternal age $(n=38,12.1 \%)$ respectively [Table-5].

Table-5: Indication of repeat caesarean section $(n=313)$

\begin{tabular}{|l|c|c|}
\hline Indication & Number & Percentage \\
\hline Refused VBAC & 105 & 33.4 \\
\hline Post dated pregnancy & 40 & 12.8 \\
\hline Advanced maternal age & 38 & 12.1 \\
\hline Previous 2 caesarean section & 20 & 6.4 \\
\hline Medical complications & 18 & 5.8 \\
\hline Scar tenderness & 16 & 5.1 \\
\hline PPROM & 16 & 5.1 \\
\hline Oligohydrmnios & 15 & 4.8 \\
\hline Breech presentation & 12 & 3.8 \\
\hline Non-reassurring CTG & 10 & 3.2 \\
\hline Short spacing & 9 & 2.9 \\
\hline BOH & 6 & 2.0 \\
\hline Fetal distress & 6 & 2.0 \\
\hline Twin & 2 & 0.6 \\
\hline
\end{tabular}

\section{DISCUSSION}

The incidence of caesarean section in this study is $31.1 \%$ which is higher compared to the WHO recommendation. ${ }^{1}$ However, it is similar to the incidence in USA (32.2\%) as reported by National Center for Health Statistics. ${ }^{2}$ Within the country, other studies had much higher CS rates than this study ranging from $45.8 \%$ to $63 \% .{ }^{1,8,9}$ However, it is higher than the finding of Okhaldhunga Community Hospital (9.5\%) and Mid-Western Regional hospital (18.8\%). ${ }^{6,7}$ Compared to other countries, it is more than in Ethiopia (27.6\%) and Libya (23.2\%) but less than India (56\%). ${ }^{4,11,15}$ Such difference may be due to difference in the referred in cases with multiple medical complications, department's policies regarding management of cases like dystocia, breech, fetal distress, reduced fetal movement, previous CS, medico-legal aspect and maternal choice.

The elective CS rate of $12 \%(n-190)$ is lower than in studies done by Dhakal et al $(17 \%)$ and Prasad et al $(23.4 \%){ }^{7,8}$ In Ethopia, the incidence of primary CS was $68.7 \%$ and elective CS was $9.6 \%$ which is comparable to this study. ${ }^{4}$ Eljazahaf et al observed that the incidence of elective CS was $23.3 \%$ in Libya whereas Pandya et al reported its incidence in India to be $42.8 \% .^{11,16}$

Similar to this study majority of women who underwent CS belonged to 20-29 year age group in other studies (84\%-70.5\%)., ${ }^{4,71}$ Pradhan et al and Prasad et al reported that majority of women (44.4\%, 42.8\% respectively) belonged to $25-29$ years. ${ }^{1,7}$ In contrast, Eljazahaf et al found that the $46.6 \%$ women belonged to $30-40$ years age group. ${ }^{8} \mathrm{As}$ in this study similar higher incidence of CS (55\%) was seen in nullipara in studies done by Samdal et al, Pradhan et al, and Dhakal et al (59.3\%,65\% and $88.5 \%$ respectively). ${ }^{1,6,7}$ Majority of the women $(89.2 \%)$ had CS at term which is similar to other studies. ${ }^{4,8,17}$

Highest number of CS was performed for fetal distress (31.5\%) in this study which is similar to other studies $\left(40.2 \%, 20.7 \%\right.$ and $19.5 \%$ respectively). ${ }^{1,7,8}$ However, in other studies it was the second leading cause. ${ }^{4,6,11,17}$ Previous $\mathrm{CS}$ is second leading indication in this study (19.7\%) which is similar to the findings of Moges et al and Dhakal et al. ${ }^{4,7}$ In contrast to this, Mascarello et al, Pandya et al and Badge et al found it to be the first leading indication for CS ${ }^{12,15,16}$ In this study, CPD is the third most common indication of CS (13.4\%) which is comparable to the findings of Prasad et al $(10.8 \%) .{ }^{8}$ In contrast, Moges et al reported very high incidence (38.1\%) of CPD in Ethiopia. ${ }^{4}$ Abnormal presentation is the fourth commonest indication (7.9\%) for CS in this study. Similar observation $(8.5 \%)$ was also reported by Prasad et al at Kathmandu Medical College. ${ }^{8}$ In contrast to this, Dhakal and Samdal et al reported its higher incidence in their studies (15.8\% and $25.3 \%$ respectively). ${ }^{6,7}$ Leitch et al also observed that number of CS has been raised for breech presentation in both in primigravida and multiparous women. ${ }^{18}$ 


\section{CONCLUSIONS}

In this study, higher incidence of caesarean section may be mainly due to the referral of complicated cases from the periphery of the country. As fifty percent of women in this study were primigravida, there may be more caesarean sections in future because of prior caesarean delivery. Along with this there can be more complications in future related with uterine scar, like abnormal placentation, haemorrhage, uterine rupture, scar pregnancy, peripartum hysterectomy as well as increased maternal and perinatal mortality.

\section{REFERENCES}

1. Pradhan P, Shrestha S, Rajbhandari PK, Dangal G. Profile of Caesarean Section in Kirtipur Hospital. NJOG. 2014;9 (2):51-4

2. Betrán AP, Ye J, Moller AB, Zhang J, Gülmezoglu AM, Torloni MR. The increasing trend in caesarean section rates global, regional and national estimates: 1990-2014. PLoS One. 2016;11(2):e0148343.

3. WHO recommendation non-clinical interventions to reduce unnecessary caesarean section. Geneva: World Health Organization. 2018

4. Moges A, Ademe B, Akessa G. Prevalence and outcome of caesarean section in Attat Hospital, Gurage Zone, SNNPR, Ethiopia. Arch Med. 2015;7(4):1-6

5. Miseljic N, Basic E, Miseljic S. Causes of an Increased Rate of Caesarean Section. Materia socio-medica. 201;30(4):287-9.

6. Samdal LJ, Steinsvik KR, Pun P, Dani P, Roald B, StrayPedersen B et al. Indications for Cesarean Sections in Rural Nepal. J Obstet Gynecol India. 2016;66(1):284-8

7. Dhakal KB, Dhakal S, Bhandari S. Profile of Caesarean Section in Mid-Western Regional Hospital in Nepal. J Nepal Health Res Counc. 2018;16(1):84-8.

8. Prasad A, Bhandari G, Saha R. Profile of Caesarean Section at Kathmandu Medical College. J Nepal Health Res Coun. $2017 ; 15(2): 110-3$.

9. Chaudhary R, Raut KB, Pradhan K. Prevalence and Indications of Cesarean Section in a Community Hospital of Western Region of Nepal. J Nep Med Assoc. 2018;56(213):871-4

10. Dickininson JE. Caeserean section. In: Lames DK, Steer PJ, Weiner CP, Gonik B editors. High Risk Pregnancy. $4^{\text {th }}$ ed Missouri: Elseiver. 2011.p1269-80.
11. Elzahaf RA, Ajroud S. Prevalence and indication of cesarean section in Al-Wahda Hospital, Derna, Libya: a retrospective study. Libyan J Med Sciences. 2018;2(2):68-72.

12. Sri AS, Khanam N. An institutional study of cesarean delivery on maternal request. Int J Reprod Contracept Obstet Gynecol. 2017;6(7):2879-82.

13. Ji H, Jiang H, Yang L, Qian X, Tang S. Factors contributing to the rapid rise of caesarean section: a prospective study of primiparous Chinese women in Shanghai. BMJ open. 2015;5(11):e008994

14. Mascarello KC, Matijasevich A, Barros AJ, Santos IS, Zandonade E, Silveira MF. Repeat cesarean section in subsequent gestation of women from a birth cohort in Brazil. Reproductive health. 2017;14(1):102.

15. Badge VL, Aggarwal SS, Ambalkar DD, Humne A, Raghuwanshi N. Assessment of indications of lower section caesarean section at tertiary care centre: a cross sectional study. Int $\mathrm{J}$ Com Med Public Health. 2017;4(4):1253-6.

16. Pandya JM, Pandya MJ, Joshi JM, Velani SP. Analytical study of indications of cesarean section. Int J Reprod Contracept Obstet Gynecol. 2015;4(5):1460-3.

17. Begum T, Rahman A, Herfina Nababan DM, Hoque E, Al Fazal Khan TA, Anwar I. Indications and determinants of caesarean section delivery: evidence from a population-based study in Matlab, Bangladesh. PloS one. 2017;12(11):1-16.

18. Leitch CR, Walker JJ. The rise in caesarean section rate: the same indications but a lower threshold. BJOG. 1998;105(6):621-6. 